\title{
CELLULAR REACTION TO COMPLEXES FORMED BETWEEN RHEUMATOID FACTOR AND AGGREGATED HUMAN GAMMA GLOBULIN
}

\author{
BY \\ N. WILLIAMSON AND N. R. LING \\ From the Rheumatism Research Wing, Department of Experimental Pathology, University of Birmingham
}

During the course of experiments to investigate whether the addition of heat-denatured 7S $\gamma$-globulin to rheumatoid leucocytes would produce transformation of the lymphocytes, an interesting phenomenon was observed. No specific stimulation of the lymphocytes was seen, but intracellular inclusions in neutrophils and macrophages, accompanied by extracellular bodies, were noted after culture of the cells for a few days. The extracellular bodies in stained smears were pale, eosinophilic, round structures, varying considerably in size and arranged either singly or in clusters. Frequently a surrounding ring of lymphocytes was seen.

Because both intracellular and extracellular structures were almost invariably present when serum from rheumatoid patients was employed, but were absent when normal serum was used, they have been called "rheumatoid cells and bodies" (R.A. cells and R.A. bodies). Reports from a number of sources suggest that bodies similar to those we describe are particularly prone to appear in fluids from rheumatoid patients. Duthie (1964) reported the formation of structures of this type when rheumatoid blood was mixed with rheumatoid synovial fluid. Parker and Schmid (1962) and Astorga and Bollet (1964) have described inclusion bodies in normal leucocytes resulting from phagocytosis of precipitates produced by the interaction of rheumatoid factor and aggregated $\gamma$-globulin. Since the present work was completed, Hollander and his colleagues (Hollander, McCarty, Astorga, and Castro-Murillo, 1965; Rawson, Abelson, and Hollander, 1965; Restifo, Lussier, Rawson, Rockey, and Hollander, 1965) have described inclusion bodies in leucocytes present in synovial fluids from rheumatoid patients and have discussed the possibility that such bodies may be formed from complexes of rheumatoid factor with autologous $\gamma$ globulin. The present paper describes the "rheumatoid cell" and "rheumatoid body" and discusses their significance and possible diagnostic use. A brief account of the chief findings has already been presented (Williamson and Ling, 1964).

\section{Material and Methods}

\section{Human $\gamma$-globulin}

Gamma globulin from three sources was used in experiments to investigate the formation of the rheumatoid body. Ethanol fractionated (Cohn fraction II) $\gamma$-globulin was most commonly used, but $\gamma$-globulin prepared by ether fractionation (Lister Institute) or by treatment with DEAE-cellulose (Stanworth, 1960) was also used. A 2.5 per cent. solution of the $\gamma$-globulin in saline was sterilized by filtration through a millipore filter and aggregated by heating for $10 \mathrm{~min}$. at $63^{\circ} \mathrm{C}$.

Fluorescent studies were undertaken using $\gamma$-globulin conjugated with fluorescein isothiocyanate. The conjugate was prepared by the following method:

The $\gamma$-globulin (100 mg. in $5 \mathrm{ml}$. saline) was added slowly, with mixing, to a suspension of fluorescein isothiocyanate ( $5 \mathrm{mg}$.) in buffered saline $(5 \mathrm{ml}$. saline plus $1.5 \mathrm{ml} .0 .5 \mathrm{M}$ sodium carbonate-bicarbonate buffer, $p \mathrm{H} \mathrm{9.0)}$. The mixture was stirred for 1 hour, and then left at $4^{\circ} \mathrm{C}$. overnight. In the morning the $p \mathrm{H}$ was adjusted to $7 \cdot 0$ with $0.2 \mathrm{~N} \mathrm{HCl}, 2$ volumes of 27 per cent. sodium sulphate were added, and after standing at room temperature for at least $2 \mathrm{hrs}$, the preparation was centrifuged at 6,000 r.p.m. for $20 \mathrm{~min}$. at $30^{\circ} \mathrm{C}$. The precipitate was washed twice in 18 per cent. sodium sulphate and then taken up in $5 \mathrm{ml}$. phosphate buffered saline $(p \mathrm{H} \mathrm{7.4)}$, dialysed overnight against this buffer, and stored at $4^{\circ} \mathrm{C}$.

It was sterilized by filtration, aggregated by heating, and centrifuged to remove any deposit.

\section{Immunological Methods}

The latex slide-agglutination test (Hyland RA test) for rheumatoid factor, the Waaler-Rose test (Gibson and Ling, 1956) and the immuno-fluorescent test for antinuclear factor (Friou, 1957) were performed on all sera investigated.

Antisera used for immunofluorescent studies were raised in rabbits, using, where possible, specific antigen; for the indirect or "sandwich" technique an antiserum to rabbit $\gamma$-globulin was raised in a goat. The spectrum of 
activity of antisera was assessed by immuno-electrophoresis. The $\gamma$-globulin fractions of the antisera were conjugated with fluorescein isothiocyanate using the method described earlier for conjugation of $\boldsymbol{\gamma}$-globulin. Unconjugated fluorescein and non-specific fluorescent material were removed by dialysis overnight followed by passage through a column of G25 sephadex (George and Walton, 1961) and absorption with guinea-pig liver powder (Nairn, 1962).

\section{Microscopy}

A Reichert Binolux microscope was used for examination of the smears and all fluorescent-and photo-micrography.

\section{Frozen Sections}

Tissues or cell preparations were embedded in gelatin and sections cut on a freezing microtome (Frigistor).

\section{Staining Methods}

A series of standard staining techniques (Culling, 1963; Dacie and Lewis, 1963) was applied to smears made from cultures. One slide with numerous bodies was stained and photographed, and the stain removed, so that repeat staining with other reagents could be carried out.

The following stains were used:

(1) Jenner-Giemsa

(2) Haematoxylin and eosin

(3) Methyl green and pyronin

(4) Feulgen

(5) Fluorescent Feulgen

(6) Azure A

(7) Periodic acid-Schiff

(8) Sudan black

Immunofluorescent studies using the following specific fluorescein conjugates were performed:

(1) Anti-human IgG (7S $\gamma$-globulin)

(2) Anti-human IgM (19S $\gamma$-globulin)

(3) Anti-human serum albumin

(4) Anti-human serum $\beta$-lipoprotein

(5) Anti-human fibrinogen

(6) Anti-human platelet

(7) Anti-human complement (Anti $\beta 1 \mathrm{C}$ )

(8) Serum from a case of systemic lupus erythematosus with high anti-nuclear factor titre

(9) Aggregated $\gamma$-globulin

\section{Patients Studied (Table I)}

Leucocyte-rich plasma or serum was obtained from twenty cases of established rheumatoid arthritis, two of systemic lupus erythematosus, one of hypogammaglobulinaemia, one of Still's disease, one of ankylosing spondylitis, one of macroglobulinaemia, one of dermatomyositis, one of scleroderma, and five healthy individuals.

The cells from 27 synovial fluids were examined. Of these synovial fluids, 21 were from the knee joints of ten rheumatoid patients, and the other six were from three non-rheumatoid patients (one osteo-arthritis, one ankylosing spondylitis, and one diabetic amputation specimen)

Standard Method for the Demonstration of Rheumatoid Cells and Bodies

Blood was collected aseptically in preservative-free heparin (20 units $/ \mathrm{ml}$. blood) in a screw-capped bottle. The blood was allowed to sediment at $37^{\circ} \mathrm{C}$. for one hour, either naturally, or after the addition of $1 / 10$ th volume of 6 per cent. dextran* in saline. The upper plasma layer, containing most of the W.B.C. but very few R.B.C., was sampled for counting and $0.5 \mathrm{ml}$. aliquots were distributed into $5-\mathrm{ml}$. bijou bottles containing $2.5 \mathrm{ml}$. culture medium and 2 drops of a 2.5 per cent. solution of heat-aggregated $\gamma$-globulin. The tightly-capped bottles were incubated at $37^{\circ} \mathrm{C}$. for 4 days with occasional mixing.

The cell suspensions were then transferred to a $3^{\prime \prime} \times \frac{1}{2}$ tube and centrifuged lightly for $5 \mathrm{~min}$. Most of the supernatant fluid was removed and the cell deposit taken up in a residual volume of about $0.01 \mathrm{ml}$. in the tip of a clean fine Pasteur pipette. Smears were made, fixed fore $10 \mathrm{~min}$. in methanol, and stained with Jenner-Giemsa.? Other smears were either left unfixed or fixed in absolute acetone $\left(-20^{\circ} \mathrm{C}\right.$. $10 \mathrm{~min}$.) for examination by the fluorescent-antibody technique.

The culture medium used was usually Eagle's medium enriched with $1 / 10$ th volume of tryptose broth. In a few experiments Trowell's hypotonic lymphocyte medium (Trowell, 1963) gave similar results. Both media contained penicillin (200 units/ml.) and streptomycin (100 units/ml.).

\section{Guinea-pig Macrophages}

These were obtained by bronchial lavage, using the method of Myrvik, Leake, and Fariss (1961). The cells were predominantly macrophages.

* Benger's Dextraven.

TABLE I

CASES STUDIED AND RESPONSE TO AGGREGATED GAMMA GLOBULIN

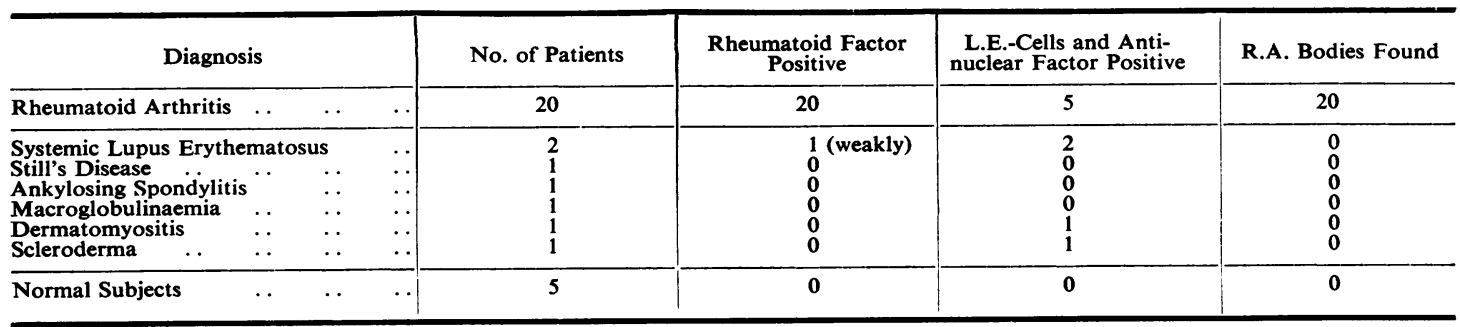


Staphylococcal Filtrate

This was prepared and used as described by Ling and Husband (1964).

\section{Results}

Rheumatoid cells and bodies (Plate $\mathrm{I} a$ and $\mathrm{I} b$, overleaf), were regularly found in smears prepared from cultures containing rheumatoid leucocytes, rheumatoid plasma and aggregated $\gamma$-globulin. The contribution of each of these three components to the formation of rheumatoid bodies was assessed.
Leucocytes.-Rheumatoid cells and bodies were produced in all cultures in which rheumatoid serum and aggregated $\gamma$-globulin had been added, irrespective of the source of leucocytes. Leucocytes from normal individuals appeared to be as effective as leucocytes from rheumatoid patients. The intracellular inclusions were observed in both neutrophils (Plate I $a$ ) and macrophages (Fig. 1). Similar bodies were also detected in guinea-pig respiratory macrophages when these were substituted for human leucocytes in cultures (Fig. 2).

Fig. 1.-“R.A. cell”, showing several inclusion bodies in a macrophage (leucocyte culture). Jenner-Giemsa. $\times 1,200$.
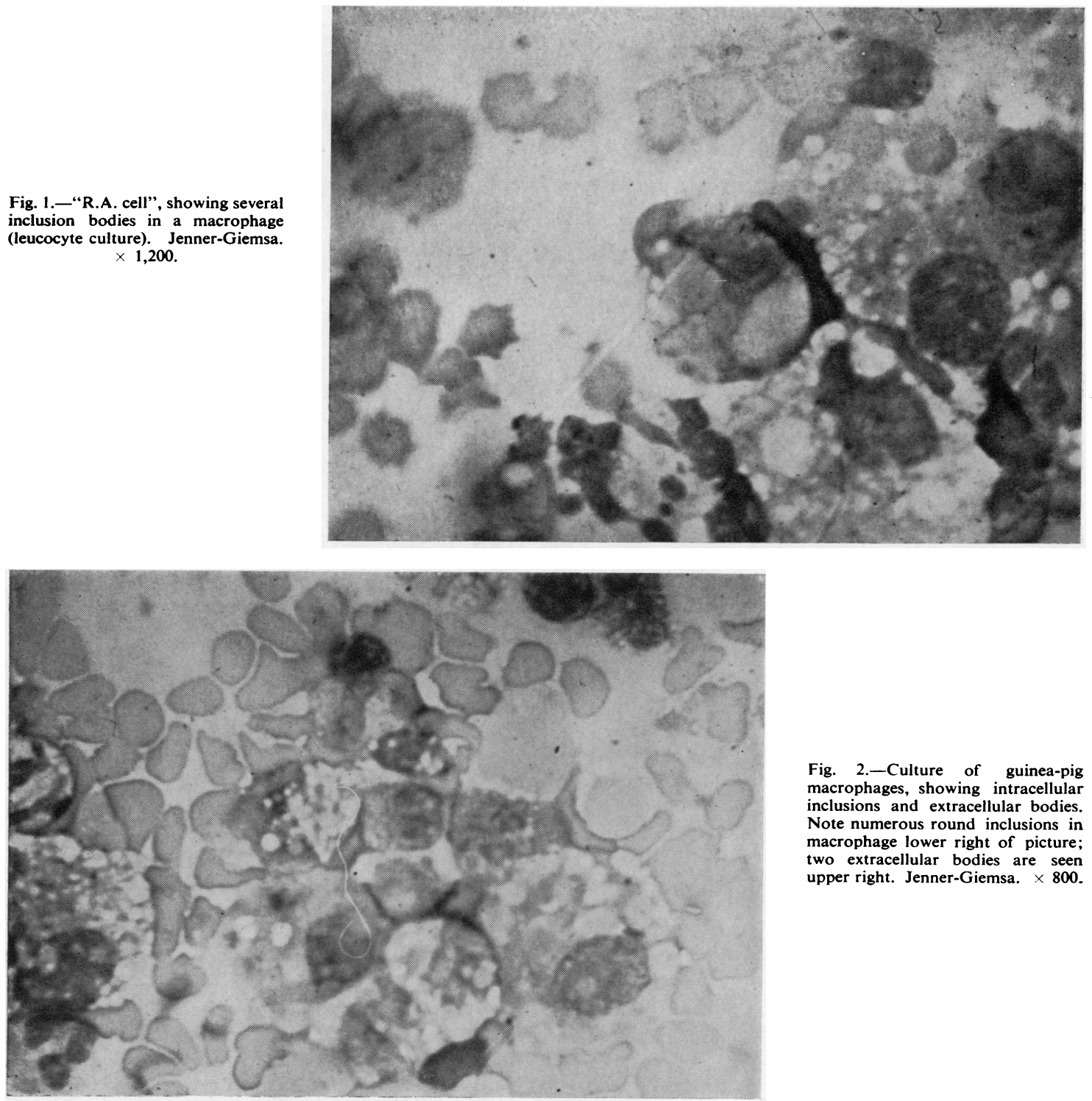

Fig. 2.-Culture of guinea-pig macrophages, showing intracellular inclusions and extracellular bodies. Note numerous round inclusions in macrophage lower right of picture; two extracellular bodies are seen upper right. Jenner-Giemsa. $\times \mathbf{8 0 0}$. 
Cultures from which leucocytes had been omitted contained amorphous deposits resulting from the interaction of rheumatoid factor and aggregated $\gamma$-globulin, but no round bodies were formed. Leucocyte cultures stored at $4^{\circ} \mathrm{C}$. overnight and then incubated at $37^{\circ} \mathrm{C}$. for 3 days were found to contain large numbers of bodies. Under these conditions, lymphocytes were the only intact leucocytes detectable in smears at the end of the culture period.

Serum.--Several variations in the concentration of rheumatoid serum were tried, but no correlation was obtained between the serum dilution and the number of rheumatoid cells or bodies produczd. Fresh rheumatoid serum gave better results than stored rheumatoid serum. The bodies were not produced when cultures contained sera from normal individuals or from a number of non-rheumatoid patients.

Gamma Globulin.-Cultures containing rheumatoid serum and leucocytes but no aggregated $\gamma$-globulin did not usually contain rheumatoid cells or bodies. Native $\gamma$-globulin was not an effective substitute for the aggregated material. On two occasions rheumatoid bodies were formed in the absence of added $\gamma$-globulin. These cultures which contained sera of exceptionally high titre with respect to rheumatoid factor may have contained $22 \mathrm{~S}$ complexes.

Lymphocyte Transformation.-No significant transformation to blast forms of the lymphocytes of rheumatoid patients occurred in the presence of aggregated $\gamma$-globulin (final concentration 0.02-2.0 $\mathrm{mg} . / \mathrm{ml}$.) over a culture period of 3 to 6 days. This was true even when the lymphocytes were washed free of autologous plasma and exposed directly to the aggregated $\gamma$-globulin or to aggregated $\gamma$-globulin in normal plasma. The typical blast transformation of human lymphocytes provoked by staphylococcal filtrate occurred in the presence as well as in the absence of aggregated $\gamma$-globulin. Stimulation of the lymphocytes seemed to have no effect on the production of bodies, nor to alter the capacity of the lymphocytes to form "rosettes" (i.e. clusters around the periphery of the larger bodies; see Fig. 3). Lymphocytes from rheumatoid patients appeared to respond to stimulation with phytohaemagglutinin and staphylococcal filtrate in exactly the same way as lymphocytes from normal individuals.

Synovial Fluid.-A final variation of the culture method consisted of using rheumatoid and normal

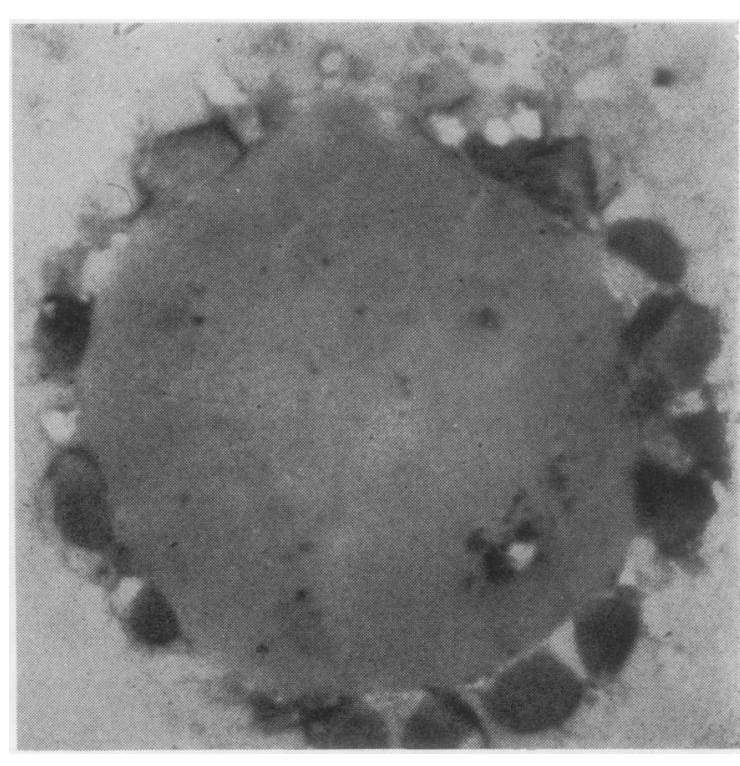

Fig. 3.-Large extracellular rheumatoid body surrounded by lymphocytes (leucocyte culture). Jenner-Giemsa. $\quad \times 1,000$.

leucocyte rich plasma to which $0.5 \mathrm{ml}$. filtered rheu-ô matoid and non-rheumatoid synovial fluid has been added. Aggregated $\gamma$-globulin was not added to these cultures. The result of this experiment was? the production of intracellular inclusions and large extracellular bodies (Plate Ic) when rheumatoid synovial fluid was used. No bodies were seen with rheumatoid leucocytes and non-rheumatoid synovial fluid. These structures were, however, somewhat different in appearance from the rheumatoid bodies (Plate $\mathrm{I} b$ ), biing granular and more basophilic when stained with Jenner-Giemsa stain.

Immunofluorescent Characterization of Rheumatoid Bodies.-The presence of IgG (7S $\gamma$-globulin) in the intracellular inclusion in R.A. cells produced by the standard technique was confirmed when it was found that these inclusions showed specific fluorescence after treatment with rabbit antiserum containing antihuman IgG labslled with fluorescein (Fig. 4, see p. 517).

The inclusions also stained brightly (Fig. 5, see p. 517) after treatment with specific fluorescent rabbit anti-human IgM (19S $\gamma$-globulin). That the IgM in the inclusion bodies was rheumatoid factor could be inferred from the fact that inclusions produced by the standard technique could also be stained with fluorescent aggregated non-immune human or rabbit $\gamma$-globulin (i.e. Mellors, Heimer, Corcos, and 


\section{CELLUAR STUDIES OF RHEUMATOID FACTOR}

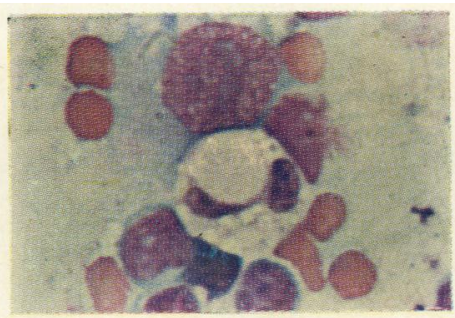

(a)

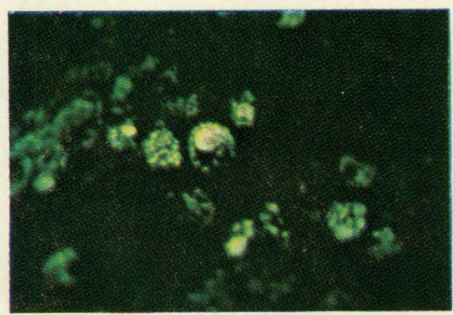

(d)

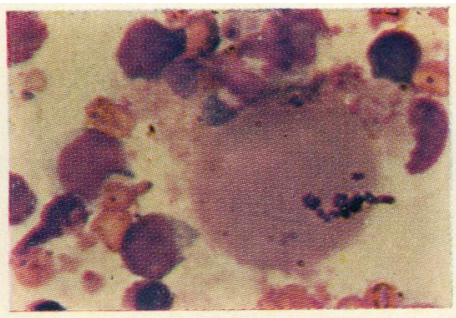

(b)

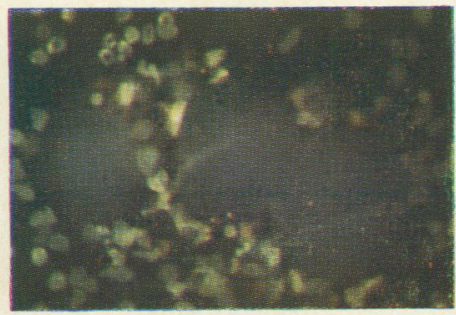

(e)

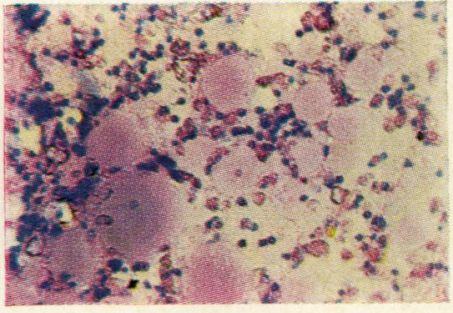

(c)

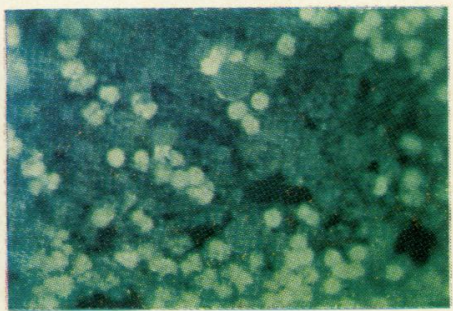

$(f)$

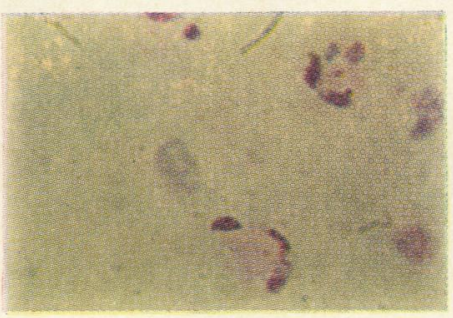

$(g)$

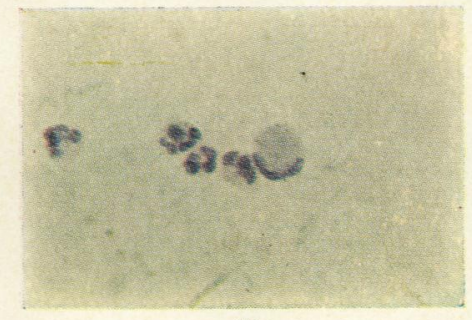

(

Plate I

(a) "Rheumatoid (R.A.) cell." Typical round inclusion seen in a polymorphonuclear cell (leucocyte culture). Jenner-Giemsa. $\times 625$.

(b) "Rheumatoid (R.A.) body." Typical extracellular body (leucocyte culture). Jenner-Giemsa. $\times 625$.

(c) Extracellular bodies produced when rheumatoid synovial fluid was added to leucocyte cultures. Jenner-Giemsa. $\times 126$.

(d) Phagocytosis of fluorescein-labelled aggregated human $\gamma$-globulin (leucocyte culture). $\times 315$.

(e) Faint autofluorescent rheumatoid bodies surrounded by brightly fluorescent leucocyte nuclei (leucocyte culture). Fluorescent Feulgen. $\times 200$. (f) Smear treated with serum from a patient with a high antinuclear factor titre followed by a fluorescein-conjugated-antihuman- $\gamma$ globulin serum. The leucocyte nuclei are stained brightly, but the rheumatoid bodies (top and bottom centre) are unstained except for a peripheral ring of fluorescence (cf. Fig. 7.) (leucocyte culture). $\times 200$.

(g) "Rheumatoid (R.A.) cell" seen in a smear of cells from synovial fluid from a patient with rheumatoid arthritis. Note eosinophilic staining. Haematoxylin and eosin. $\times 625$.

(h) Typical L.E.-cell found in a smear of cells from synovial fluid from a patient with rheumatoid arthritis. Note haematoxyphilic staining ( $c f$. Plate I $g$ ). Haematoxylin and eosin. $\quad \times 400$. 
Fig. 4.-“R.A. cell". Inclusion bodies show bright staining with a fluorescein-conjugated antiserum to human IgG (7S $\gamma$-globulin) (leucocyte culture). $\times 1,400$.

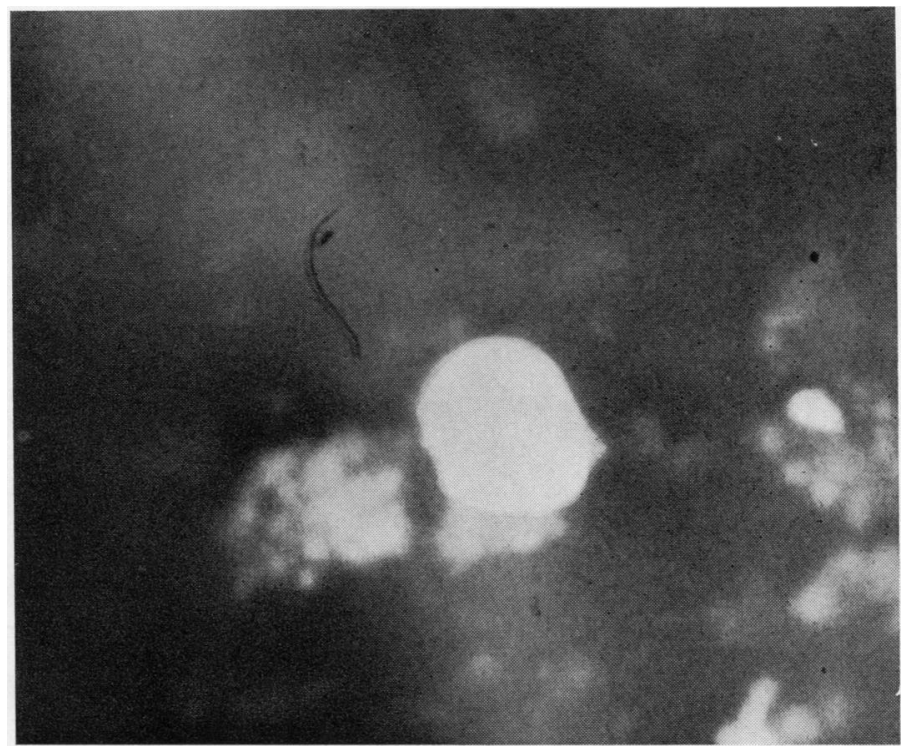

Korngold, 1959; McCormick, 1963). No staining was obtained with anti-human $\beta$-lipoprotein, antiplatelet serum, anti-fibrinogen and anti-complement (anti- $\beta 1 C)$.

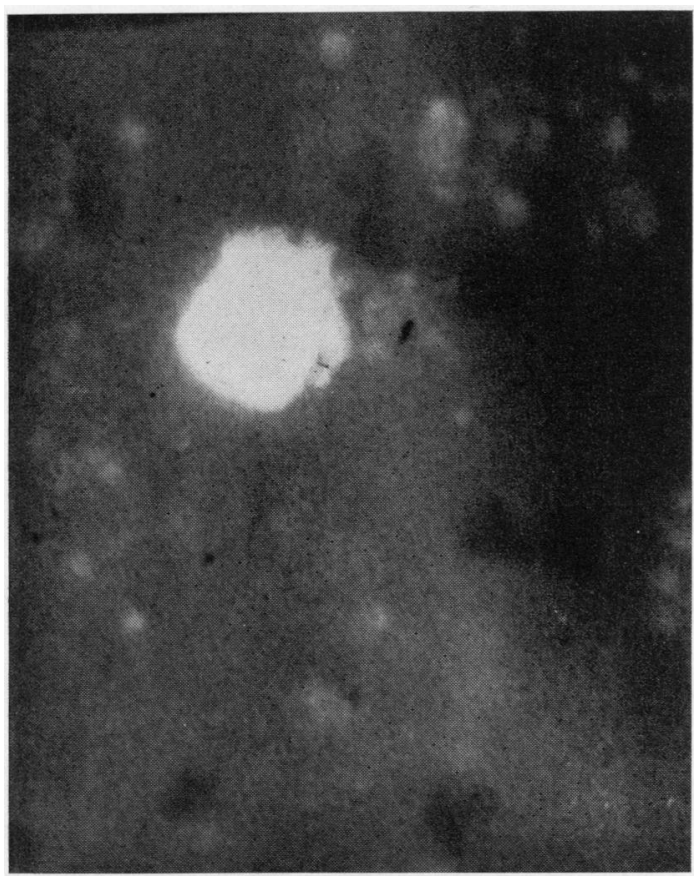

Fig. 5.-“R.A. cell". Inclusion bodies show bright staining with a fiuorescein-conjugated antiserum to human IgM (19S $\gamma$-globulin) (leucocyte culture). $\times 1,135$.
Mode of Formation of R.A. Cells and Bodies.On incubating rheumatoid serum with fluorescent aggregated $\gamma$-globulin for prolonged periods in the absence of cells, amorphous granular masses of fluorescent precipitates were observed to form. On adding leucocyte suspensions at this stage, phagocytosis of precipitate occurred with the formation of typical R.A. cells containing fluorescent granules and larger spherules (Plate $\mathrm{I} d$ ). With more prolonged incubation, degeneration and disintegration of the neutrophils and macrophages was observed and the numbers of extracellular R.A. bodies, which were also fluorescent, increased. In the case of the larger R.A. bodies, a reticulated pattern could sometimes be discerned, suggesting that these bigger structures had been formed by fusion of smaller ones (Fig. 6, overleaf).

When the intracellular R.A. bodies formed by the standard technique were examined by the immunofluorescent technique they, like the intracellular inclusions, failed to stain with anti- $\beta$-lipoprotein, anti-platelet serum, anti-fibrinogen and anti-complement (anti- $\beta 1 C)$. But significant differences were observed between the intra and extracellular particles in their staining reactions with anti-IgG, anti-IgM, and anti-albumin. The intracellular inclusions stained uniformly with anti-IgG and anti-IgM, but failed to stain with anti-albumin. The extracellular bodies showed bright fluorescence at the periphery 


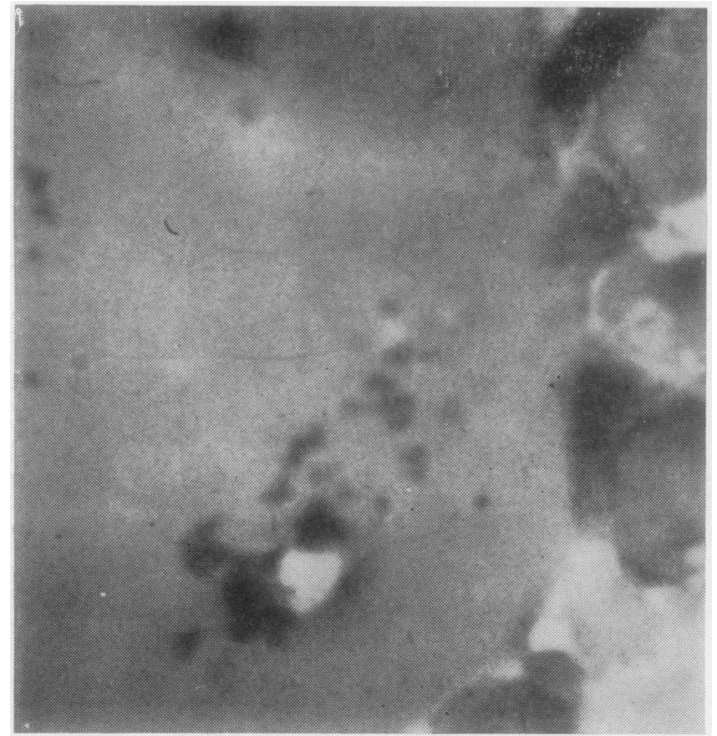

Fig. 6.-High-power magnification of Fig. 3, showing the somewhat reticulated appearance of these larger bodies (leucocyte culture). Jenner-Giemsa. $\quad \times 1,900$.

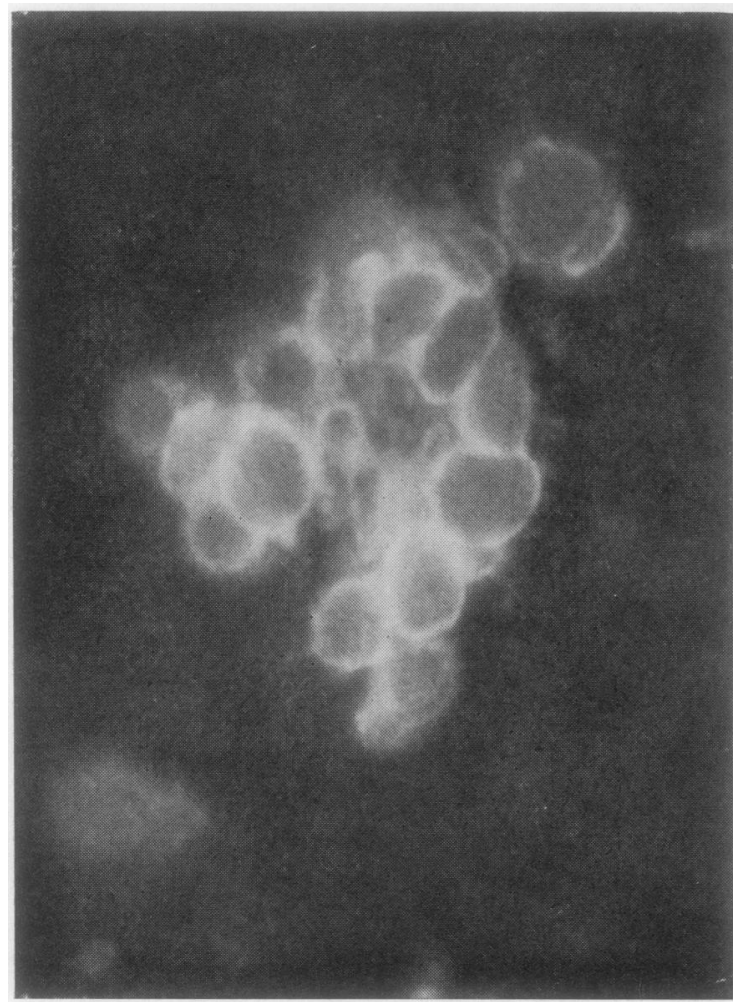

Fig. 7.-Extracellular rheumatoid bodies stained with fluoresceinconjugated antiserum to human IgG. Note bright peripheral staining but unstained central area (leucocyte culture). $\times 800$. with anti-IgG and anti-IgM, while the central area stained relatively faintly (Fig. 7). This appearance did not seem to be an artefact accountable to the greater thickness of the extracellular bodies, since similar appearances were given in both smears and frozen sections of the bodies. Moreover, the extracellular bodies stained uniformly with anti-albumin (Fig. 8). A possible explanation for this difference in staining reactions between the intra and extracellular particles is propounded below.

Differentiation of R.A. Cells from L.E. Cells.In view of the wide variations reported in the incidence of the occurrence of L.E. cells in rheumatoid arthritis (e.g. Marmont, 1959; Glynn and Holborow, 1964) and the superficial morphological similarity between R.A. cells and L.E. cells, it seemed important to investigate means of distinguishing between these phenomena.

When the staining characteristics of R.A. cells and L.E.-cells were compared, using a number of

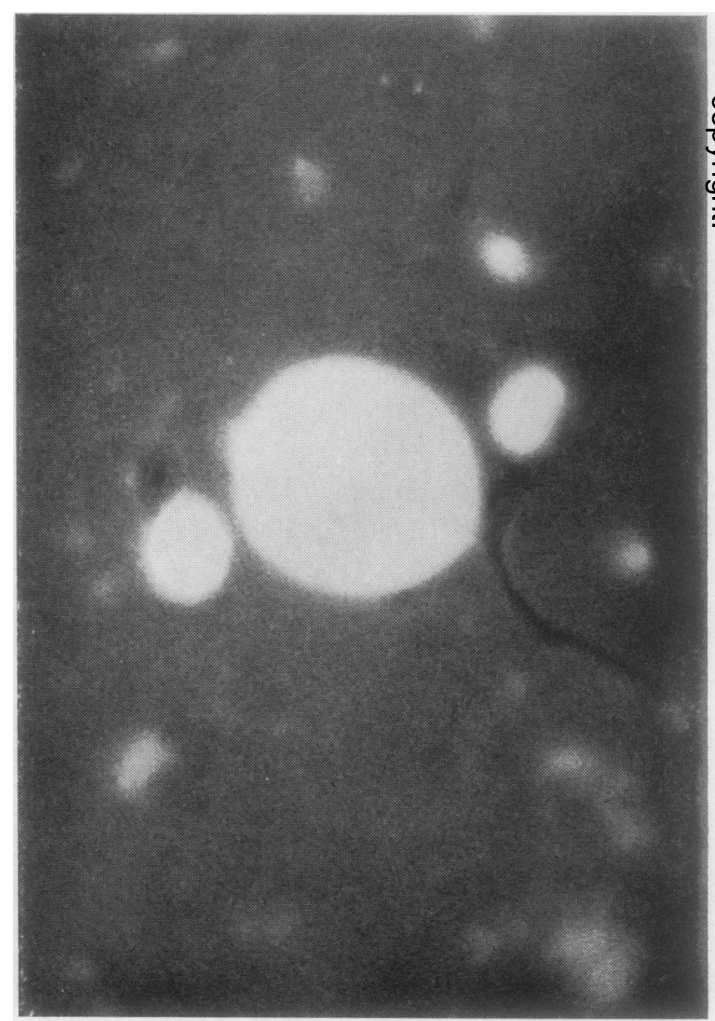

Fig. 8.-Extracellular rheumatoid bodies stained with a fluoresceinconjugated antiserum to human serum albumin. Note that the whole body shows bright fluorescence (leucocyte culture). $\quad \times 600$. 
conventional histological methods, several points of difference became apparent (Table II). Of these, the most significant was the failure of the intracellular inclusion body in the R.A. cell to give any of the staining reactions of desoxyribonucleic acid (i.e. negative Feulgen reaction, lack of fluorescence with the fluorescent Feulgen stain (Plate I $e$ ), pale pyroninophilic staining with methyl green pyronin stain, and eosinophilic staining with a haematoxylin and eosin stain). This was further confirmed when it was found that the intra and extracellular material produced by the standard technique failed to fluoresce when treated first with a systemic lupus erythematosus serum followed by fluorescent anti $\gamma$-globulin, although the nuclei of surrounding cells fluoresced strongly (Plate $\mathrm{I} f$ ).

TABLE II

STAINING REACTIONS OF THE R.A. BODY AS COMPARED WITH THE L.E.-CELL

\begin{tabular}{|c|c|c|}
\hline Stain Used & R.A. Body & L.E.-Cell \\
\hline $\begin{array}{l}\text { Jenner-Giemsa } \\
\text { Haematoxylin and }\end{array}$ & $\begin{array}{l}\text { Eosinophilic } \\
\text { Eosinophilic }\end{array}$ & $\begin{array}{l}\text { Basophilic } \\
\text { Haematoxyphilic }\end{array}$ \\
\hline Methyl green and & Faintly pink & Green \\
\hline $\begin{array}{l}\text { Feulgen } \\
\text { Fluorescent Feulgen } \\
\text { Azure A }\end{array}$ & $\begin{array}{l}\text { Negative } \\
\text { Negative } \\
\text { Unstained or faintly } \\
\text { metachromatic }\end{array}$ & $\begin{array}{l}\text { Positive } \\
\text { Positive } \\
\text { Blue }\end{array}$ \\
\hline $\begin{array}{l}\text { Periodic acid-Schiff } \\
\text { Sudan black }\end{array}$ & $\begin{array}{l}\text { Weakly positive } \\
\text { Unstained }\end{array}$ & $\begin{array}{l}\text { Negative } \\
\text { Unstained }\end{array}$ \\
\hline
\end{tabular}

The initial comparison was carried out between cases falling clearly into one or the other disease category with no overlap. On the other hand, when sera from five cases of rheumatoid disease with positive L.E.-cell tests were examined, no R.A. bodies were observed in the control cultures (without added aggregated $\gamma$-globulin) although occasional small basophilic bodies were noted after 4 days' culture. These were easily distinguishable from the large crop of R.A. bodies produced on adding aggregated $\gamma$-globulin. But it was noted that the R.A. bodies, in these circumstances, were somewhat more basophilic than those occurring in the serum of L.E.-cell negative rheumatoid cases.

While we have not yet encountered the spontaneous formation of R.A. bodies in L.E.-cell preparations, it should be noted that R.A. cells and L.E.-cells can each occur spontaneously in synovial fluid (Plate I $g$ and $h$ ). The difference in staining between these structures (as outlined in Table II) may then conceivably be of assistance in differentiating the two conditions.

Specificity of R.A. Cell Formation in relation to Other Connective Tissue Diseases.-R.A. cells and bodies were observed in preparations from all twenty rheumatoid patients, but none was seen in preparations from five healthy individuals or from eight patients with the other connective tissue diseases listed (Table I). In particular, it was interesting to note that the serum from one patient (who had a negative Waaler-Rose test, but a positive latex-slide titre of 1:400 and otherwise clinically classical rheumatoid arthritis) produced numerous R.A. cells and bodies. On the other hand, the serum from a patient with systemic lupus erythematosus containing anti-nuclear factor and rheumatoid factor (latex positive, Waaler-Rose titre $=1$ in 16) failed to produce R.A. cells or bodies in the standard test.

In cases giving positive results, the number of R.A. cells and bodies varied considerably, and, as yet, no quantitative assay seems practicable. For example, no acceptable correlation has been obtained between the concentration of rheumatoid factor in the serum (as judged by the Waaler-Rose titre) and the numbers of R.A. cells formed under standard conditions.

\section{Discussion}

From the experiments described, it is clear that R.A. cells are formed when rheumatoid factor and aggregated $\gamma$-globulin interact to form a complex in the presence of phagocytes. The phagocytic cells may be of human or animal origin, and appear to behave in all cases identically in ingesting the complex and moulding it into spherical bodies. Following ingestion, the complex appears to be relatively resistant to digestion by the cells, since even after many hours of incubation the individual components of the complex can still be identified by immunofluorescent techniques. With prolonged incubation and as death and disintegration of the leucocyte occur, the intracellular inclusions are released once more into the medium, retaining their spherical form (as distinct from the amorphorus masses characterizing rheumatoid-factor-aggregated $\gamma$-globulin precipitates formed in vitro in the absence of cells) and sometimes attracting collections of lymphocytes to form "rosette"-like structures.

The rheumatoid-factor-aggregated- $\gamma$-globulin complex within the cell was found to stain uniformly with anti-IgM and anti-IgG antisera, but failed to stain with anti-albumin. The extracellular bodies showed bright staining around the periphery with the anti-immunoglobulin sera but stained uniformly with anti-albumin. This suggests that, after release from the cell, the bodies imbibe serum components from the surrounding medium.

R.A. cells and bodies bear a superficial morphological resemblance to L.E.-cells and bodies. How- 
ever, in typical, clear-cut cases of rheumatoid arthritis and of S.L.E., it appears unlikely that confusion will arise. R.A. cells and bodies, in our experience to date, do not usually occur spontaneously in cultures of peripheral blood cells, but can only be induced by the addition of aggregated $\gamma$-globulin to the system. Moreover, when so formed, the inclusion bodies lack the basophilic staining character of L.E.-cell inclusion bodies and fail to give any of the histochemical or immunochemical reactions of nuclear material.

Contrariwise, the few sera of cases of systemic lupus erythematosus which we have examined have not given rise to R.A. cells on adding cells and aggregated $\gamma$-globulin.

Nevertheless, in cases of "classical" rheumatoid arthritis in which the L.E.-cell test is positive, we have observed that the intracellular inclusions in the R.A. cells are more basophilic, suggesting inclusion of nuclear material. It is possible that rheumatoid factor may interact with the antigen-antibody complex formed between antinuclear factor and nuclear material, as suggested, on other grounds, by McCormick and Day (1963). This may account for the "L.E.-like cells" or "atypical L.E.-cells" described by some authors (e.g. Marmont, 1959).

It is similarly possible that the R.A. body may be mistaken for the extracellular "Lupus Glob" or haematoxyphil body. For example Arterberry, Drexler, and Dubois (1964) reported the presence of haematoxylin bodies in 26 out of 38 cases of rheumatoid arthritis, while L.E.-cells were demonstrable in only twelve of these cases.

The present limited series has suggested that R.A. cell formation is relatively specific to rheumatoid arthritis among the "collagen" diseases. But it is possible that the occurrence of "atypical L.E.-cells" in other conditions characterized by the frequent occurrence of anti-globulin antibodies (e.g. "lupus hepatitis" and some cases of bacterial endocarditis) might be explicable on a similar basis.

Our observations on the occurrence of rheumatoid bodies were initially incidental to attempts to stimulate lymphocytes of rheumatic patients with autoantigens. Other workers (e.g. Hollander and others, 1965), approaching the matter from entirely different viewpoints, have observed similar inclusion bodies in leucocytes from rheumatoid patients. ZuckerFranklin (1964) examined the ultrastructure of inclusions in various types of leucocytes obtained from the blood, lymph, and synovial fluid of patients with rheumatoid arthritis. In addition to phagocytosed material in neutrophils, she found, in cells belonging to the lymphoid series, inclusions occupying distended cisternae of rough endoplasmic retic- ulum, suggesting that the material had actually been manufactured by these cells.

Restifo and others (1965) propose that complexes of rheumatoid factor and IgG, which are phagocytosed by leucocytes, may be directly implicated in the pathogenesis of joint inflammation. Whether or not this should prove to be the case, there is no doubt that the special tendency of these complexes and bodies to occur in fluids from rheumatoid patients is worthy of further attention.

\section{Summary}

Intracellular and extracellular bodies were produced when aggregated $\gamma$-globulin was added to cultures of leucocyte-rich plasma from rheumatoid patients. Similar cells and bodies were found to occur in synovial fluid smears from rheumatoid patients.

Histochemical and immunofluorescent studies were undertaken to establish the nature of these structures.

The specificity and significance of this phenomenon in rheumatoid arthritis is discussed, and the possible application to diagnosis is considered.

We are indebted to Dr. K. W. Walton for help and advice, to Dr. C. F. Hawkins, Dr. L. Holt, and Dro H. J. Gibson for the supply of blood and synovial fluids and to Professor P. G. H. Gell, Dr. J. F. Soothill, anc Dr. P. Wolf for the various antisera. This work was aided by a grant from the Nuffield Foundation.

\section{REFERENCES}

Arterberry, J. D., Drexler, E., and Dubois, E. L. (1964) J. Amer. med. Ass., 187, 389.

Astorga, G., and Bollet, A. J. (1964). Arthr. and Rheum., 7, 288.

Culling, C. F. A.. (1963). "Handbook of Histopathological Techniques", 2nd ed, pp. 199-268. Butterworths, London.

Dacie, J. V., and Lewis, S. M. (1963). "Practical Haematology", 3rd ed, p. 50 and p. 81. Churchill, London.

Duthie, J. J. R. (1964). "Symposium on Polyarthritis", Proceedings Royal College of Physicians, Edinburgh, p. 83.

Friou, G. J. (1957). J. clin. Invest., 36, 890.

George, W., and Walton, K. W. (1961). Nature (Lond.), $192,1188$.

Gibson, H. J. and Ling, N. R. (1956). Ann. rheum. Dis., $15,246$.

Glynn, L. E., and Holborow, E. J. (1964). In "Textbook of the Rheumatic Diseases", 3rd ed., ed. W. S. C. Copeman, p. 112. Livingstone, Edinburgh.

Hollander, J. L., McCarty, D. J., Jr., Astorga, G., and Castro-Murillo, E. (1965). Ann. intern. Med., 62, 271. 
Ling, N. R., and Husband, E. M. (1964). Lancet, 1, 363.

Marmont, A. (1959). In "Immunopathology: First International Symposium, Basel, 1958", ed. P. Grabar and P. Miescher, p. 479. Schwabe, Basel.

McCormick, J. N. (1963). Ann. rheum. Dis., 22, 1.

—_ and Day, J. (1963). Lancet, 2, 554.

Mellors, R. C., Heimer, R., Corcos, J., and Korngold, L. (1959). J. exp. Med., 110, 875.

Myrvik, Q. N., Leake, E. S., and Fariss, B. (1961). J. Immunol., 86, 128.

Nairn, R. C. (1962). "Fluorescent Protein Tracing", p. 117. Livingstone, Edinburgh.

Parker, R. L., and Schmid, F. R. (1962). J. Immunol., 88, 519.

Rawson, A. J., Abelson, N. M., and Hollander, J. L. (1965). Ann. intern. Med., 62, 281.

Restifo, R. A., Lussier, A. J., Rawson, A. J., Rockey, J. H., and Hollander, J. L. (1965). Ibid., 62, 285.

Stanworth, D. R. (1960). Nature (Lond.), 188, 156.

Trowell, O. A. (1963). Exp. Cell Res., 29, 220.

Williamson, N., and Ling, N. R. (1964). Paper presented to the Pathological Society of Great Britain and Ireland, July, 1964.

Zucker-Franklin, D. (1964). Arthr. and Rheum., 7, 760.
La réaction cellulaire contre les complexes formés entre le facteur rhumatoide et la gamma globuline agrégée humaine

\section{RÉSUMÉ}

On a produit des corps intracellulaires et extracellulaires en ajoutant de la gamma globuline agrégée aux cultures du plasma riche en leucocytes des malades atteints d'arthrite rhumatismale. On a recontré des cellules et des corps similaires dans des frottis du liquide synovial des malades rhumatisants.

On a procédé à des études histochimiques et immunofluorescents pour déterminer la nature de ces structures.

On discute la spécificité et l'importance de ce phénomène dans l'arthrite rhumatismale et on considère la possibilité de son application diagnostique.

La reacción celular contra los complejos formados entre el factor reumatoide y la gamma globulina agregada humana

\section{Sumario}

Cuerpos intracelulares y extracelulares fueron producidos al añadir la gamma globulina agregada a cultivos de plasma enriquecidos con leucocitos de enfermos con artritis reumatoide. Células y cuerpos similares fueron encontrados en los frotis del líquido sinovial de enfermos reumáticos.

Se hicieron estudios histoquímicos e inmunofluorescentes para determinar la naturaleza de estas estructuras.

Se discuten la especifidad y la importancia de este fenómeno en la artritis reumatoide y se considera la posibilidad de su aplicación diagnóstica. 